\title{
Determinants of Income from Fish Marketing in Ibarapa Area of Oyo State, Nigeria
}

\author{
Adeosun Olubunmi and Adebukola Folake Bankole \\ Department of Fisheries Technology, Oyo State College of Agriculture, Igbo-ora \\ E-mail: moriyike2006@yahoo.com, flakylee@yahoo.co.uk
}

\begin{abstract}
This study was carried out to assess the market structure, the socio-economic characteristics of the fish marketers and determinants of revenue generated from fish marketing in Ibarapa towns using purposive sampling, which cut across age, and sex of fish sellers in dtw0 each location. Ninety-four percent of fish marketers were women and their men counterpart were $6.0 \%$ with an average sales of 5,123.00k per day. Double-log model indicated a relationship between the determinant of fish revenue(Y) and some explanatory variables which include: average price of fish (X1), transportation cost (X2), average sales per day (X3) and duration of sales per day (X4) at $p=0.01$. The elasticity of all variables determining the revenue generated from fish are less than one. Thus a percentage increase in average price of fish and transportation cost lead to 0.7404 and 0.3242 percentage increases in revenue generated from fish marketed per unit time respectively. Conversely, a percentage increase in duration of sales per day and average sales per day leads to -0.20745 and -0.1549 percentage decrease in quantity of fish marketed per unit time in the study area.
\end{abstract}

Keywords: Fish retailers, Revenue, Fish marketing, and Distribution channel

\section{Introduction}

Fish marketing may be broadly defined as all those functions involved from the point of catching of fish, to the point of final consumption. As the fish, like any other production moves closer and closer to the ultimate consumer, the selling price increases since the margins of the various intermediaries and functionaries are added to it. The pricing efficiency is concerned with improving the operation of buying, selling and other connected aspects of marketing process so that it will remain responsive to consumer direction. Several studies that examined the marketing system of fish and its implication for agricultural and economic development in Nigeria in general have employed the relationship between costs and selling prices of fish (Ali et al, 2008).

Marketing and distribution channels are important characteristics in the process of getting produce from source to consumers. Olukosi and Isitor (1990) categorized marketing channels into centralized and decentralized channels. Centralized channels deals with agents who serve as middleman between producers an $d$ consumers while decentralized is a kind of channel where both consumers and agents can buy, directly from the producers (Madugu and Edward, 2011). Fish distribution channel is common to most developing countries with series o f middlemen between producers and consumers (Moses, 1992). Eyo (2001) stressed that processed fish is sold as smoked or dried without varieties as fish fingers, cakes and other ready to serve fish foods to stimulate wider interest in marketing, distribution and consumption. Fish supply and marketing suffer from various setbacks ranging from shortage of supply, price fluctuations due to drying up of source, poor distribution and length of chain, spoilage in transit etc. (Tomek and Robinson, 1981). Furthermore, due to the cumbersome nature of fish distribution channel, the local fish seller is faced with the problem of profit maximization. Therefore, the objectives of this study are to identify the determinants of fish revenue, fish distribution channels and to ascertain fish products forms available in the study area.

\section{Methodology}

The study was conducted in Ibarapa. Ibarapa region falls within latitude $7^{0} 15^{\prime} \mathrm{N}$ and $7^{0} 55^{\prime} \mathrm{N}$ and longitude $3^{0} 00^{\prime} \mathrm{E}$. Ibarapa region comprises of three local governments namely Ibarapa east, Ibarapa North, and Ibarapa central. Ibarapa region is consists of seven famous towns which are Lanlate, Eruwa, Igboora, Idere, Ayete, Tapa and Igangan. There are daily, evening, morning and periodic market in each of the town in Ibarapa region. Prominent amongst the market is 5day Maya market, which is about d-2 7kilometre north of Lanlate. Maya market remains the major commercial poin 0 ts of exchanges between the local farmers and traders xpnd-2 from various part of south western Nigeria. Also other prominent markets are Okolo in Eruwa, Ilado in Lanlate, Talabi in between Tapa and Igangan and Towobowo market in Igboora where traders from all towns and Ibarapa converged for trade transaction.

\section{Data Collection and Sampling Procedure}

The selection of respondents was carried out using purposive sampling, which cut across age and sex of fish sellers. The five major towns that were surveyed include: Igboora, Lanlate, Tapa, Ayete and Eruwa. One hundred questionnaires were administered to the respondents. Questions were asked based on the objectives of the study, data on general information i.e. demographic factors such as age, sex, educational level and years of experience. It also provides information on their sources of supply (distribution channel), the cost incurred on transportation of fish from sources of supply, variation in price of fish with respect to time they recorded nigh sales of fish and also the problems encountered by fish sellers. 


\section{Analytical Technique}

Both numerical and statistical analyses of data were employed. These involved descriptive analysis of data by calculating parameters such as means, frequency distribution, simple proportion, percentages and the use of tables. Tables are presented where necessary to relate one variable to another. Also, percentage was employed to test variables. Ordinary Leas t Multiple Regression analysis was employed to estimate the determinant of revenue generated from fish marketed. The socio-economic characteristic of the marketers was analyzed through the use of descriptive statistic. The model stated below was used in identifying the determinants of revenue generated from fish marketed.

$$
\begin{aligned}
& \mathrm{Y}=\mathrm{bo}+\mathrm{blxl}+\mathrm{b} 2 \mathrm{x} 2+\mathrm{b} 3 \mathrm{x} 3+\mathrm{b} 4 \mathrm{x} 4+\mathrm{el} \\
& \mathrm{Y}=\text { revenue generated from fish marketed } \\
& \mathrm{X} 1=\text { average price of fish } \\
& \mathrm{X} 2=\text { duration of sales per day (in hour) } \\
& \mathrm{Y} 3=\text { transportation cost. } \\
& \mathrm{X} 4=\text { average sales per day. } 1=\text { error term }
\end{aligned}
$$

\section{Marketing Channels}

Marketing channels were identified using the respondents and the route through which fish was transferred from producers or wholesalers to consumers and a distribution channel was drawn.

\section{Result and Discussion Socio-economic characteristics}

The socio-economic characteristics of fish marketers in Ibarapa which include age, gender, educational status and years of experience are presented in Table 1 . Data show that more than half of the fish marketers (51.0\%) were between the ages of 41-50 while those between 31-40 and 51-60 years were $21.0 \%$ and $20.0 \%$ respectively. This implies that most of the marketers are in their active economic years. The table also shows that most of the respondents were female (94.0\%) while only $6.0 \%$ were male. This means that female marketers dominate marketing of fish in the study area. Lawal and Idega (2004) also found out that $90 \%$ of women participated in fish marketing in Benue State. The work of Madugu and Edward (2011) revealed that both men (50\%) and women (50\%) are involved in fish marketing in Adamawa State. Response on years of experience in fish selling indicates th at majority of the respondents $(84.0 \%)$ had between $5-20$ years experience in fish marketing while $9.0 \%$ and $7.0 \%$ had $<5$ and $>20$ years of experience respectively. This is an indication that risk will be well managed since they have gained mastery of the business over the years. Sevilleja (2000), Edwards (2000), and Dey et.al (2000) agreed that experience is crucial and is contributing to the success of Asian aquaculture. The table also reveals that $21.0 \%$ of the respondents have no formal education, $59.0 \%$ have primary education, while $5 \%$ have tertiary and $15.0 \%$ have secondary education. The high literacy level of $79.0 \%$ of the respondents is enough to support information on technology use. Ridler and Hishamunda (2001) reported that successful cage farmers in Niger Republic is at minimal literate and this corr oborated in Fawole and Fashina (2005) on association of education with the use of technology on organic fertilizer. Frozen fish (60\%) constituted a majority of the fish marketed followed by smoked fish (24\%), fried fish (13\%) while the remaining 3.0\% were live fish. Amao et.al (2006) who reported that in Lagos large proportion of respondents (58) accounted for about 53 percent of the sampled respondents preferred catfish to any other type of fish, about 22 percent preferred tilapia, while 18 percent and 7 percent preferred Mackerel and Stock fish respectively. This showed that, majority of the respondents in the study area preferred frozen fish to Marine fish or live catfish.

\section{Major Problems Faced by Fish Marketers in the Study Area}

Response on major problems faced by fish retailers is presented in Table 3. Data revealed that $56.0 \%$ were faced with problem of storage facilities, $20.0 \%$ of the sellers were encountered with problem of handling practices. $7.0 \%$ of the sellers have loss on investment while $17.0 \%$ of the sellers have no problem. The response confirmed that majority of the sellers in the study area faced with problem of storage facilities, this could be attributed to poor electricity supply usually experienced in the area which is highly needed for preserving frozen fish which is in high demand in this region.

How to Cite this Article: Adeosun Olubunmi and Adebukola Folake Bankole, "Determinants of Income from Fish Marketing in Ibarapa Area of Oyo State, Nigeria” Science Journal of Agricultural Research \& Management, Volume 2012, Article ID sjarm-135, 6 Pages, 2012. doi: 10.7237/sjarm/135 
Table 1: Socio-economic Characteristics of fish retailers in Ibarapa Area

\begin{tabular}{|c|c|c|}
\hline Characteristics & Frequency & Percentage \% \\
\hline \multicolumn{3}{|l|}{ Age (yrs) } \\
\hline $21-30$ & 4 & 4 \\
\hline $31-40$ & 25 & 25 \\
\hline $41-50$ & 51 & 51 \\
\hline $51-60$ & 20 & 20 \\
\hline TOTAL & 100 & 100 \\
\hline \multicolumn{3}{|l|}{ Gender } \\
\hline Female & 94 & 94 \\
\hline Male & 6 & 6 \\
\hline TOTAL & 100 & 100 \\
\hline \multicolumn{3}{|c|}{ Educational level } \\
\hline Illiterate & 21 & 21 \\
\hline Primary & 59 & 59 \\
\hline Secondary & 15 & 15 \\
\hline Tertiary & 5 & 5 \\
\hline Total & 100 & 100 \\
\hline \multicolumn{3}{|c|}{ Marketing Experience Interval (yrs) } \\
\hline$<5$ & 9 & 9 \\
\hline $5-10$ & 39 & 39 \\
\hline $11-15$ & 24 & 24 \\
\hline $16-20$ & 21 & 21 \\
\hline$>20$ & 7 & 7 \\
\hline Total & 100 & 100 \\
\hline \multicolumn{3}{|l|}{ Product Form } \\
\hline Frozen & 60 & 60 \\
\hline Live & 3 & 3 \\
\hline Smoked & 24 & 24 \\
\hline Fried & 13 & 13 \\
\hline Total & 100 & 100 \\
\hline
\end{tabular}

Field data 2012

Table 2: Major problems faced by Respondents

\begin{tabular}{lll}
\hline Constraints & Frequency (f) & Percentage (\%) \\
\hline Handling practice & 20 & 20 \\
Storage facilities & 56 & 56 \\
Loss on investment & 7 & 7 \\
No problem & 17 & 17 \\
\hline
\end{tabular}

Field data 2012 


\section{Distribution Channels}

The distribution channels of the different fish species in Ibarapa area are represented in figures 1- 3.

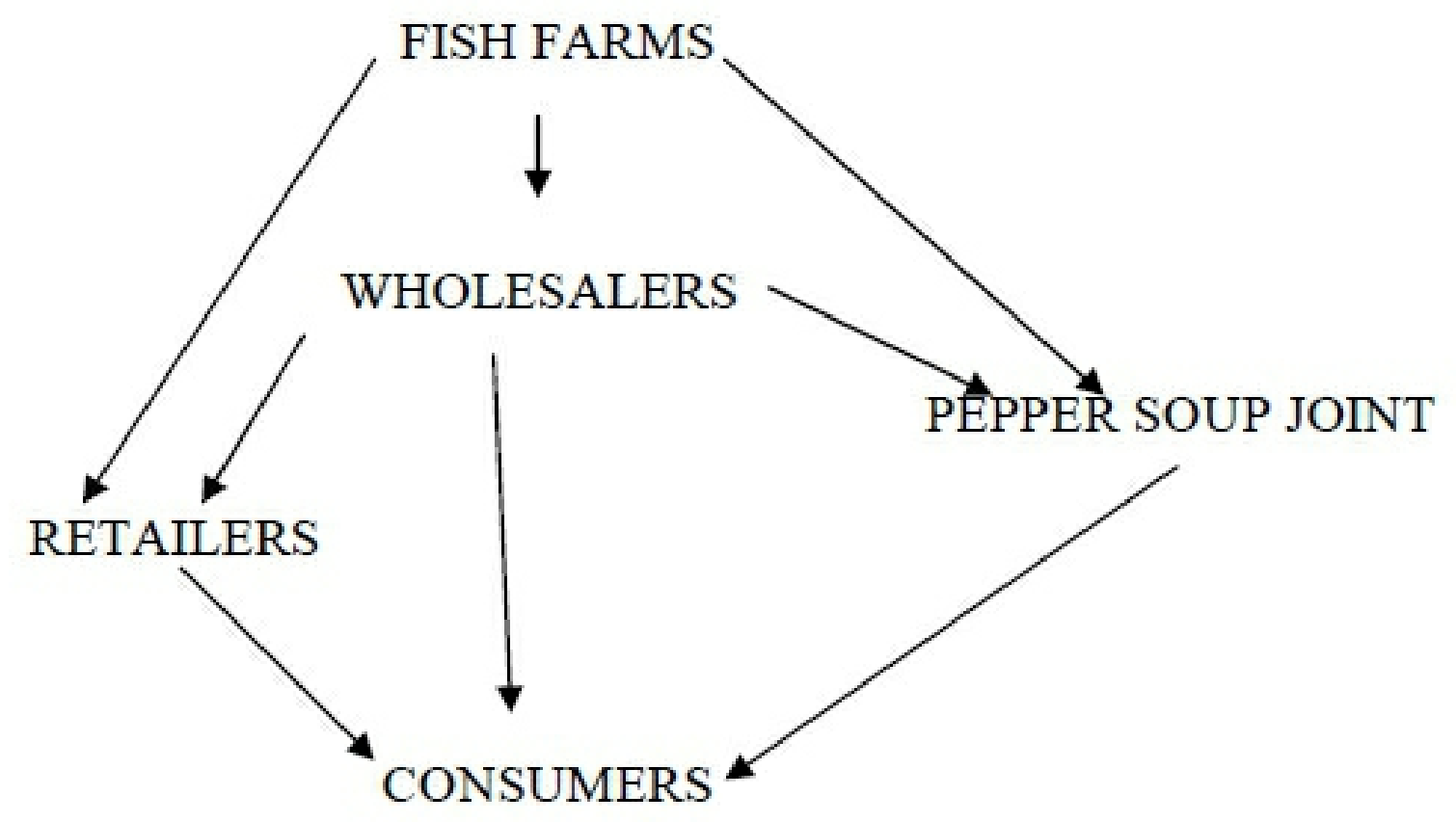

FIG. 1 Live Fish Distribution Channel in Ibarapa

Figure 1 shows that live fish retailers and pepper soup joint operators either buys from fish farmers or wholesalers and consumers will either buy from wholesaler or retailers. Figure 2 shows the distribution channel of frozen fish. The consumers either purchase frozen fish from the retailers or directly from the cold room while smoked fish is purchased from fish processors or fishermen wife (fig.3).

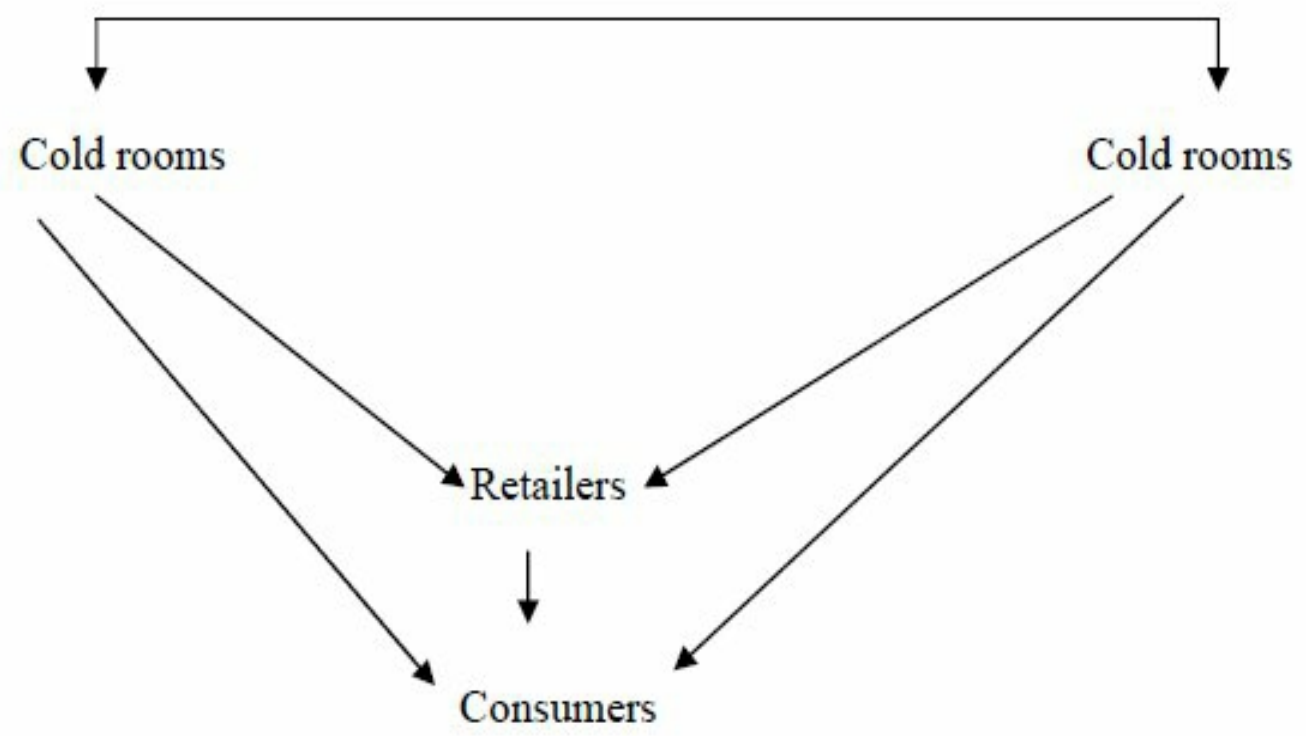

Fig. 2 Frozen Fish Distribution Channel in Ibarapa 


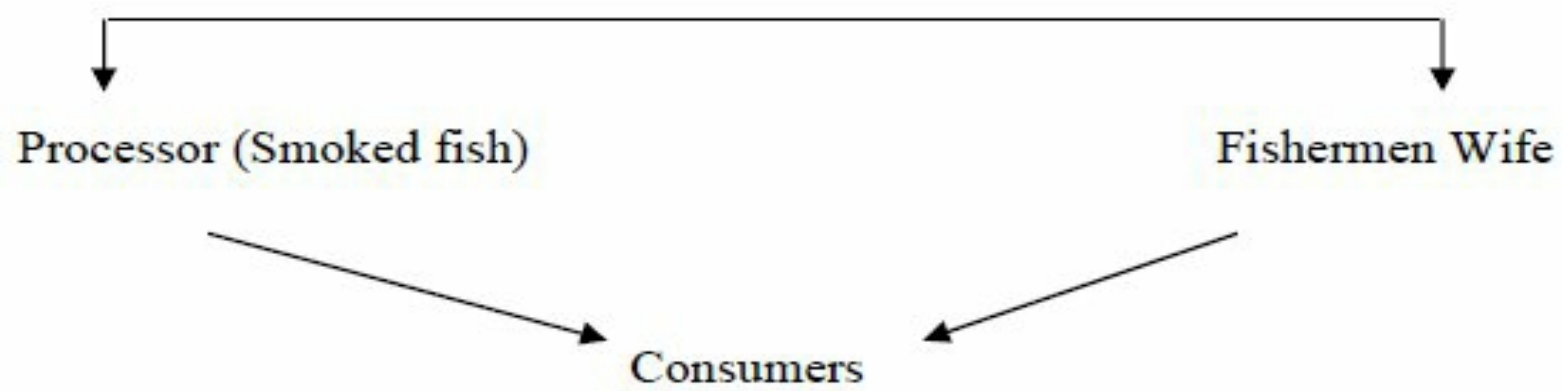

Fig. 3 Smoked Fish Distribution Channel in Ibarapa

\section{Regression Analysis Results}

The total number of fish marketed depends on a number of socio economic factors. The model applied indicated a relationship between the determinants of fish revenue $(\mathrm{Y})$ and some explanatory variables which include: average price of fish
(X1), transportation cost (X2), average sales per day (X3), duration of sales per day (X4). To determine the impact of the factors, a multiple regression was used. Four alternative model or functional forms were experimented with and these are linear, double log, semi - log and exponential function. The result is presented in the Table 3 .

\begin{tabular}{|c|c|c|c|c|}
\hline $\begin{array}{l}\text { Functional form } \\
\text { dependent variables }\end{array}$ & Linear Y & Double-log in $Y$ & Semi-log Y & Exponential in $Y$ \\
\hline Constant & $325.3515 *(167.7571)$ & $0.2381(0.6067)$ & $\begin{array}{l}-3531.81 * * * \\
(725.3902)\end{array}$ & $\begin{array}{l}5.3768^{* * *} \\
(0.1707)\end{array}$ \\
\hline Average price of fish $\left(\mathrm{x}_{\mathrm{l}}\right)$ & $1.4497^{* *}(0.4727)$ & $0.7404^{* * *}(0.9282)$ & $341.2204^{* *}(110.9838)$ & $\begin{array}{l}0.0026^{* * *} \\
(0.0005)\end{array}$ \\
\hline Transportation cost ( $\left.\mathrm{x}_{2}\right)$ & $-0.4784(0.5068)$ & $-0.0745(0.8103)$ & $-85.19919(96.8855)$ & $-0.0003(0.0005)$ \\
\hline Average Sales per day $\left(\mathrm{x}_{3}\right)$ & $0.0374^{* *}(0.0115)$ & $0.3242^{* * *}(0.7618)$ & $370.928^{* * *}(91.0814)$ & $\begin{array}{l}0.0001 \\
(0.0001)\end{array}$ \\
\hline Duration of sales per (hr) & $-62.8151(167.7571)$ & $-0.1549 * * *(0.1487)$ & $-238.9129(177.871)$ & $\begin{array}{l}0.0784 \\
(0.1057)\end{array}$ \\
\hline $\mathrm{R}^{2}$ & 0.2537 & 0.6127 & 0.339 & 0.368 \\
\hline $\mathrm{r}^{2}$ & 0.222 & 0.5955 & 0.3096 & 0.3411 \\
\hline $\mathrm{F}$ & 7.99 & 35.6 & 11.54 & 13.68 \\
\hline
\end{tabular}

*Figures in parenthesis are standard errors

***: Significant at 1\% **: Significant at $5 \%$

Table 3 shows the multiple regression result of determinants of fish price in the study area. Four regression models were fitted to the data and based on statistical, mathematical and econometric criteria, double-log model was found to be the lead equation out of the four independent variables included in the model, average fish price, volume of sales per day and duration of sales per (hr) were found to be significant at $p=0.01$. A unit increase in average fish price and the volume of sales per day will lead on the average to 0.07 and 0.15 decrease in the revenue generated from the total fish marketed respectively. The result of $\mathrm{R}^{2}$ shows that about 60 percent of dependent variables was explained by the explanatory variable included in the model. F- Statistics is

\section{*: Significant at $10 \%$}

significant at $p=0.01$ meaning that the chosen model is appropriate and fit for analysis. The relationship between average fish price and average sales per day proved that average sales per day is significant at $(p=0.01)$.

\section{Elasticity Estimates}

The elasticity of each explanatory variable change in the dependent variable that would result from a percent changes in the level of independent variables. From table 4.8, the relationship between average fish price and average sales per day proved that average sales per day is significant at $p=0.01$.

Table 4: $\quad$ Elasticity Estimates

\begin{tabular}{lllll}
\hline Variables & $\mathrm{X}_{\mathrm{l}}$ & $\mathrm{X}_{2}$ & $\mathrm{X}_{3}$ & $\mathrm{X}_{4}$ \\
\hline Estimates & 0.7404 & -0.0745 & 0.3242 & -0.1549 \\
\hline
\end{tabular}


The elasticity of all variables determining the revenue generated from fish are less than one:, this simply means that they are in-elastic .Thus, a percentage increase in average price of fish, and transportation cost lead to 0.7404 and 0.3242 percentage increase in revenue generated from fish marketed per unit time in the study area. Conversely, a percentage increase in duration of sales per day and average sales per day leads to -0.0745 , and -0.1549 percentage decrease in quantity of fish marketed per unit time in the study area.

\section{Conclusion and Recommendation}

Fish marketing is a lucrative business in the study area especially frozen fish which most of the people in the area preferred. This study revealed that the major determinant of revenue generated from fish marketed is average price of fish, transportation cost and duration of sales per day. The multiple regression result of determinants of fish price in the study area revealed that average fish price, volume of sales per day and duration of sales per ( $\mathrm{hr}$ ) were found to be significant. A unit increase in average fish price and the volume of sales per day will lead on the average to 0.07 and 0.15 decrease in the revenue generated from the total fish marketed respectively. Storage problem is the major problem facing fish marketers in Ibarapa. A large proportion of losses associated with this sector might reduce if fish sellers have cooperative associations to take advantage of economic of scale of production like collective buying and selling, investing in storage facilities which can maintain quality of product and hence give higher return to sellers. Smoked fish processing should be improved by providing kilns at affordable prices to processors and processors should be trained on Good Manufacturing Practices. There is need for improvement in major towns in the study area in terms of the provision of infrastructures such as electricity and storage facilities.

\section{References}

1. Ali E.A, H.I.M, Gaya and T.N Jampada (2008): Economic Analysis of fresh fish marketing in Maiduguri Ganboru market and kachallari Alau dam landing site of North Eastern Nigeria Journal of Agric. science, 4:23-6.

2. Amao, J.O, I.B Oluwatayo and F.K. Osuntope (2006): Economics of Fish Demands in Lagos State, Nigeria Journal of Human Ecology 19(1): 25-30 (2006) Retrieved from http://www.krepublishers.com accessed on $3 / 28 / 2012$.

3. Dey, M.M., Rab, M.A., Paraguas, F.J., PIUMSOMBUN, S., Bhatta, R., Alam,F .M., Koeshendrajana, S., and Ahmed. M (2002): Socio- Economics of Freshwater Fish Farm in Asia: Strategies and Options for Increasing and Sustaining Fisheries and Aquculture Production to Benefit Poor Household in Asia. File///A1/fish supply \& demand in Asia Progress report 2002. World Fish Center Pp 1-14.

4. Edwards, P. (2000): Aquaculture, Poverty impacts and livelihood. Overseas Development Institute No.56 June Pp1-8

5. Eyo A. A (2001): Fish processing Technology in tropics .University of Ilorin press, Nigeria.

6. Fawole O.P and Fashina.O (2005): Factors predisposing farmers to organic fertilizer use in Oyo State, Nigeria. Journal of Rural Economics and Development, vol.14.Pp81-90

7. Lawal W.L. and E.O Idega (2004): Analysis of fish marketing in Benue State. Proceedings of the 2004 Annual Conference of the National
Association of Agricultural Economists (NAAE) held at ABU Zaria, Nov. 3rd - 5th 2004

8. Madugu A.J. and A. Edward (2011): Marketing and Distribution Channel of Processed Fish in Adamawa State, Nigeria Global Journal of Management and Business Research volume 11 issue 4 version1.0 March 2010

9. Moses, B.S (1992). Introduction to tropical fisheries 2nd edition.1-125

10. Olukosi, J.O and S.U. Isitor, (1990): An introduction to Agricultural marketing and price; principle and Applications. Living books series GU Publications Abuja.115

11. Ridler, N. and Hishamunda, N. (2001) Promotion of Sustainable Commercial Aquaculture in Sub-Saharan Africa. Vol.1 Policy Framework FAO.Fisheries Technical Paper, No 408/1 FAO, 2001 Pp16.

12. Sevilleja, R.O. (2000): Adoption and Economics of Tilapia Farming Technology in the Phillippinnes. Retrieved from Oregon state.edu/dept/11FET/2000/papers/sevilleja Accessed on 3/28/2012

13. Tomek, W.G. and L. Robinson (1981): Agricultural product prices, 2nd edition. Ihaca, New York, U.S.A Cornel University press 